\title{
Study of the Phenolic Profile of Cider Apple Cultivars at Maturity by Multivariate Techniques
}

\author{
J uan J . Mangas,* Roberto Rodríguez, Belén Suárez, Anna Picinelli, and Enrique Dapena \\ Centro de Investigación Aplicada y Tecnología Agroalimentaria, Apartado 13, E-33300 Villaviciosa, \\ Asturias, Spain
}

\begin{abstract}
Phenolic compounds in 46 Spanish cider apple varieties were determined by RP-HPLC with direct injection. Several pattern recognition procedures, including principal component analysis (PCA), linear discriminant analysis (LDA), and partial least squares (PLS-1), were applied to the data in an attempt to classify the samples into bitter and nonbitter categories. Reliable decision rules were obtained by both LDA and PLS-1. LDA achieved 91.3 and $85.7 \%$ correct classification respectively, for internal and external evaluation of the model.
\end{abstract}

Keywords: Cider apple; polyphenols; direct injection HPLC; chemometric

\section{INTRODUCTION}

Various types of phenolic compounds are found in cider apple cultivars, namely, hydroxycinnamic acid derivatives, monomeric and oligomeric flavan-3-ols, dihydrochalcones, and flavonols (Picinelli et al., 1997; Guyot et al., 1998; Escarpa and González, 1998). They play an important role in browning processes and in the formation of hazes and sediments, they contribute to the flavor of processed apple products, and from the point of view of health, some of them, such as hydroxycinnamates, are an important source of antioxidants and free radical scavengers (Okuda, 1993; Chen and Ho, 1997; Donovan et al., 1998).

Many studies have dealt with the phenolic composition of apples and its relation to browning susceptibility. Enzymatic browning occurs in fruits and vegetables as a result of enzymatic oxidation of phenolic compounds into quinones, which subsequently polymerize into brown products (Nicolas et al., 1994). Quinones are highly unstable and can undergo reactions with other phenolic compounds, giving rise to dimers with an o-diphenolic structure; they can later undergo oxidation enzymatically or by coupled oxidation with o-quinones (Macheix et al., 1990a). At the same time, other nonphenolic substances such as amino or thiol groups can react with quinones, giving rise to a new o-diphenolic structure that, once oxidized, can form intensely col ored products.

Polyphenol-protein interaction (based on hydrogen and/or hydrophobic bonding) is involved in haze formation in fruit juices and alcoholic beverages, the amount of haze formed being related to polyphenol and protein levels and to their ratio (Siebert et al., 1996a). At the same time, the percentage of proline in polypeptides has also been shown to be very important in haze production; in fact, polypeptides with a high content of proline produced more haze. The nature of polyphenols is also involved in the formation of haze. In this sense, flavan3-ols dimers of $(+)$-catechin and (-)-epicatechin were

* Author to whom correspondence should be addressed (telephone 34-85890066; fax 34-85891854; e-mail juanjoma@ princast.es). found to be implicated in the formation of haze in alcoholic beverages and apple juice (Siebert et al., 1996b).

The taste of cider is dependent on the presence of flavan-3-ol derivatives. Bitterness and astringency are related to the degree of polymerization of procyanidins (Lea, 1990), the most astringent being the most polymerized procyanidins. At the same time, certain hydroxycinnamic acids are bitter (Macheix et al., 1990b) and monomers of flavan-3-ols such as $(+)$-catechin were rated bitter and astringent (Robichaud and Noble, 1990).

Polyphenol analysis is generally accomplished by RPHPLC with UV - vis detection. Due to the complexity of the analysis, two methods for polyphenol fractionation have traditionally been used: liquid-liquid extraction (Salagoity-Auguste and Bertrand, 1984; Suárez et al., 1994) and solid-liquid extraction (Lee and J aworski, 1987; Suárez et al., 1996). However, analysis of major polyphenols of low molecular mass can be carried out by direct injection following a simple treatment of the sample (Betés-Saura et al., 1996; Suárez et al., 1998). Likewise, the optimization of analytical information can be carried out by means of chemometric techniques when a large amount of data is available. For example, exploratory data analysis can be used to search for "natural" groupings of samples and to reduce dimensionality. Principal component analysis (PCA) allows reduction of the number of variables and visualization of the data structure. Linear discriminant analysis (LDA) computes a decision rule to predict the class to which a sample belongs. Partial least squares (PLS) regression allows prediction of the values of one or more dependent variables from a set of predictor variables (Massart et al., 1988; Martens and Naes, 1989; Meloun et al., 1992). When the dependent variable is the class identity, the procedure is called PLS discriminant analysis.

Although classification of cider apple varieties into technol ogical groups has been successfully done in the past using data for total polyphenols and total acidity (Beech and Carr, 1977), the information obtained by means of the analysis of global parameters can be 
limited. Because a balanced phenolic profile is desirable both to control microbiological spoilage and to guarantee flavor quality of ciders, a study of the phenolic profile of apple varieties should be necessary.

The purpose of the present work was to carry out a technological characterization of various Spanish cider apple varieties traditionally used in cider-making on the basis of their phenolic profiles.

\section{MATERIALS AND METHODS}

Samples. Spanish cider apple cultivars, grown during the 1994 (42 varieties) and 1995 (46 varieties) seasons in the experimental orchard of the CIATA (Villaviciosa, Asturias, Spain), were harvested at maturity and directly sampled (2.0$2.5 \mathrm{~kg}$ of fresh apples; 24 fruits). Apples from each variety were milled with a hammer mill and pressed by means of a small hydraulic press; the apple musts obtained were subsequently clarified by centrifugation (12000g; $5 \mathrm{~min}$ ) and frozen at $-20{ }^{\circ} \mathrm{C}$ until analysis. Ascorbic acid (10 g/L) was added to the apple juices prior to filtration through a $0.45 \mu \mathrm{m}$ cellul ose acetate membrane filter (Teknokroma, Barcelona, Spain) before chromatographic analysis.

Total polyphenols were determined according to the Montreau method (1972) and expressed as grams of tannic acid per liter; total acidity was done determined by using the AOAC procedure (AOAC, 1984) and calculated as grams of sulfuric acid per liter.

Reagents. Standards for polyphenols [chlorogenic acid, (-)epicatechin, p-coumaric acid, and phloridzin] were obtained from Sigma, Spain. Procyanidin B2 and phloretin 2-xyloglucoside were provided by Dr. Lea (Reading, U.K.) and used for identification purposes only. Methanol and acetic acid were of HPLC quality (Panreac, Barcelona, Spain) and degassed with helium prior to use.

Chromatography. Experimental data were obtained using an HPLC system (Kontron Instruments S.A., Madrid, Spain) equipped with a 465 autosampler $\left(V_{i}=25 \mu \mathrm{L}\right)$, two 422 pumps, a 440 diode array detector, and a KromaSystem 2000 software data module. Analytical separation of phenolic compounds was carried out on a Spherisorb ODS-2 column $(250 \mathrm{~mm} \times 4 \mathrm{~mm}$, $3 \mu \mathrm{m}$; Teknokroma, Barcel ona, Spain) at $35^{\circ} \mathrm{C}$, using $2 \%$ acetic acid (solvent $A$ ) and methanol (solvent $B$ ) as mobile solutions. The elution conditions were as follows: starting from $0 \%$ solvent $B$, one linear step of increase of solvent $B$ in solvent $A$ until $45 \%$ B in $55 \mathrm{~min}$; flow rate $=0.7 \mathrm{~mL} / \mathrm{min}$. I dentification of polyphenols was achieved by comparing their spectra and retention times and by spiking with the available compounds under the same conditions. Quantitation was done at $280 \mathrm{~nm}$ by the external standard method. For those analytes having no standard available, standards of the same family were used; thus, procyanidin B2 was quantitated as (-)-epicatechin, phloretin 2-xyloglucoside and the unknown dihydrochalcone were determined as phloridzin, and the unknown phenolic acid derivatives (compounds referred to as PHA) were determined as p-coumaric acid. A chromatogram of the phenolic compounds of low molecular mass is displayed in Figure 1.

Data Processing. Data were processed by means of the PARVUS statistical package (Forina et al., 1988). We constructed a data matrix $(46 \times 9)$ in which the rows (46) represented cider apple varieties harvested in 1995, and the columns (9) corresponded to phenolic compounds [an unknown phenolic acid derivative, PHAl $\left(\lambda_{\max }=316.7 \mathrm{~nm}\right)$, procyanidin B2, chlorogenic acid, (-)-epicatechin, an unknown phenolic acid derivative, PHA2 $\left(\lambda_{\max }=312 \mathrm{~nm}\right)$, phloretin 2-xyloglucoside, an unknown dihydrochalcone $\left(\lambda_{\max }=283 \mathrm{~nm}\right)$, phloridzin (phloretin glucoside), and an unknown phenolic acid derivative, PHA3 $\left(\lambda_{\max }=312 \mathrm{~nm}\right)$ ]. In addition, samples were categorized as bitter (B) or nonbitter (N), according to their total pholyphenol contents. Samples included in the bitter category presented total phenol levels $>1.5 \mathrm{~g} / \mathrm{L}$, whereas the nonbitter category were $<1.5 \mathrm{~g} / \mathrm{L}$. The data were autoscaled before multivariate analysis. A binary variable $(Y)$ was defined to construct the PLS model, with the following values: $Y=1$

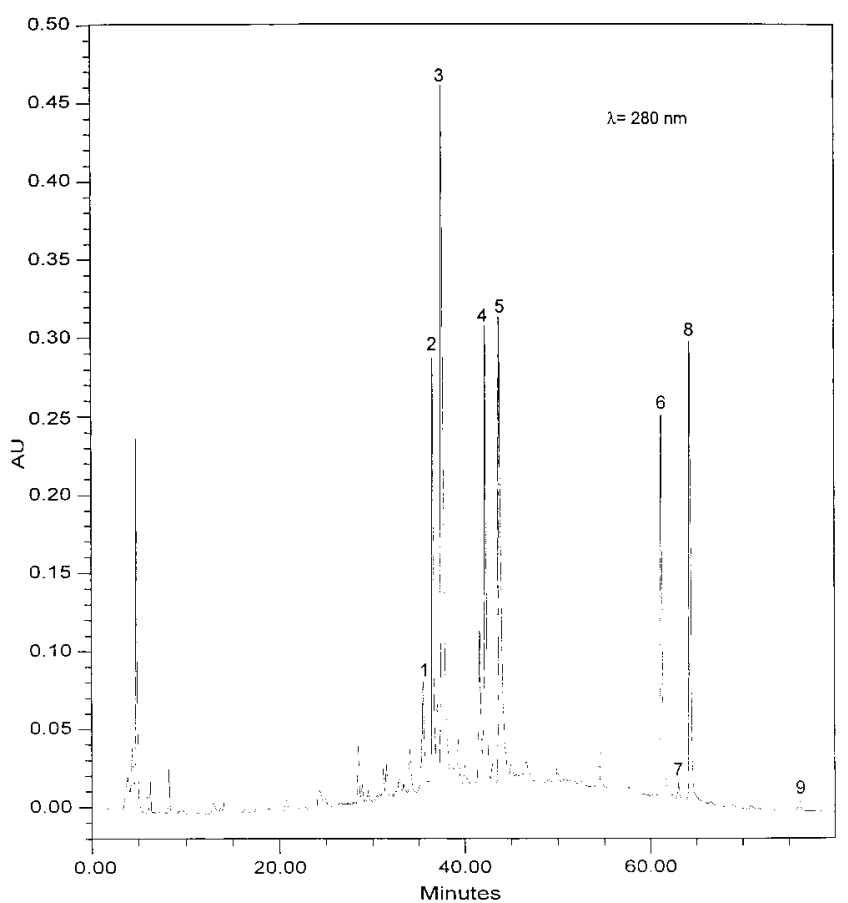

Figure 1. Chromatogram of phenolic compounds of a Spanish cider apple variety: 1, Unk PHA1; 2, procyanidin B2; 3, chl orogenic acid; 4, (-)-epicatechin; 5, Unk PHA2; 6, phloretin 2-xyloglucoside; 7, Unk dihydrochalcone; 8, phloridzin; 9, Unk PHA3.

for the nonbitter class and $Y=2$ for the bitter class. The 42 cider apple varieties harvested in 1994 were included in an evaluation set to evaluate the LDA analysis.

\section{RESULTS}

Data for polyphenol compounds, total phenols, and total acidity are presented in Tables 1 and 2. Major phenols were chlorogenic acid, (-)-epicatechin, and procyanidin B2. Chlorogenic acid (CA) was, in general, the main compound among the phenols determined; only a few samples exhibited higher contents for (-)epicatechin and procyanidin B2 (varieties referred to as 12, 13, 14 and 34, both in 1995 and 1994, as seen in Tables 1 and 2). Mean contents of procyanidin B2 and (-)-epicatechin were 38.37 and $44.27 \mathrm{mg} / \mathrm{L}$, respectively. Among phenolic acid derivatives, that referred to as $\mathrm{PHA} 2$ was the main one, with mean contents of 10.44 $\mathrm{mg} / \mathrm{L}$, ranging between 0.00 and $68.34 \mathrm{mg} / \mathrm{L}$ during harvest of 1994.

Dihydrochal cone glucosides, such as phloridzin and phloretin 2-xyloglucoside, are characteristic of apples. Phloretin 2-xyloglucoside contents were usually higher than those for phloridzin, whereas the unknown dihydrochalcone was absent in several varieties. The t test showed no significant differences for phenolic compound contents between years at the $95 \%$ confidence level.

Total phenols and total acidity are represented as histograms in Figure 2 for the 88 observations. As seen in Figure 2 a, the main group of varieties $(62.5 \%)$ was represented in the range from 0.8 to $1.3 \mathrm{~g} / \mathrm{L}$, whereas only $11.4 \%$ of the samples presented total phenol contents $>1.9 \mathrm{~g} / \mathrm{L}$. Total acidity was mainly comprised between 4.00 and $5.50 \mathrm{~g} / \mathrm{L}$ (55.7\%, Figure $2 \mathrm{~b}$ ). These parameters are usually employed for the classification of apples into technological groups; however, this information can be limited, because nothing is said about differences in the quantitative phenolic profiles of apple varieties. 
Table 1. Phenolic Compound Concentrations in Apple J uice Cultivars (1995 Harvest)a

\begin{tabular}{|c|c|c|c|c|c|c|c|c|c|c|c|c|c|}
\hline \multirow[b]{2}{*}{ variety } & \multicolumn{13}{|c|}{ polyphenols (mg/L) } \\
\hline & ref & PHAl & B2 & CA & $E$ & PHA2 & Ph XyG & Unk & Ph G & PHA3 & $\Sigma$ & TP & $\overline{\mathrm{TA}}$ \\
\hline Calabaza & 1 & 1.32 & 26.02 & 125.72 & 25.98 & 15.32 & 22.26 & 1.12 & 6.82 & 0.61 & 225.17 & 1.43 & 5.76 \\
\hline Campillo & 2 & 2.71 & 37.64 & 70.91 & 46.16 & 0.00 & 65.56 & 3.21 & 11.53 & 0.48 & 238.20 & 1.15 & 3.80 \\
\hline Durón Arroes & 3 & 1.13 & 11.86 & 136.40 & 23.43 & 2.92 & 18.91 & 0.81 & 9.85 & 0.76 & 206.07 & 1.19 & 3.80 \\
\hline Dolores & 4 & 0.70 & 3.97 & 109.19 & 11.63 & 9.39 & 29.23 & 1.23 & 10.09 & 0.63 & 176.06 & 0.79 & 3.80 \\
\hline Lagar & 5 & 1.15 & 0.00 & 246.38 & 80.97 & 15.03 & 107.18 & 6.52 & 8.71 & 0.67 & 466.61 & 2.40 & 4.66 \\
\hline Miyares & 6 & 1.12 & 42.35 & 46.47 & 42.93 & 21.87 & 38.17 & 2.11 & 11.38 & 0.64 & 207.04 & 1.58 & 3.43 \\
\hline Reineta Encarnada & 7 & 0.49 & 35.80 & 96.50 & 44.68 & 6.11 & 6.75 & 0.00 & 4.36 & 0.79 & 195.48 & 1.10 & 3.19 \\
\hline Repinaldo Hueso & 8 & 0.58 & 27.39 & 149.40 & 33.12 & 0.00 & 4.98 & 0.00 & 2.50 & 0.35 & 218.32 & 1.30 & 4.04 \\
\hline Loroñesa & 9 & 1.04 & 7.90 & 228.12 & 12.21 & 13.34 & 26.34 & 1.20 & 7.89 & 0.48 & 298.52 & 1.56 & 3.80 \\
\hline Montoto & 10 & 2.22 & 67.30 & 138.10 & 68.36 & 0.00 & 26.85 & 1.65 & 6.13 & 0.50 & 311.11 & 1.65 & 4.04 \\
\hline Parda Carreño & 11 & 0.58 & 6.90 & 160.29 & 11.72 & 0.00 & 42.38 & 2.48 & 12.31 & 0.59 & 237.25 & 1.10 & 3.92 \\
\hline Parda Blanquera & 12 & 4.47 & 246.92 & 128.53 & 206.54 & 35.41 & 32.54 & 1.15 & 32.39 & 0.61 & 688.56 & 2.25 & 5.39 \\
\hline Loroñe & 13 & 3.47 & 127.32 & 79.50 & 114.97 & 22.38 & 23.84 & 0.84 & 26.62 & 0.49 & 399.43 & 1.99 & 3.92 \\
\hline Meana & 14 & 2.18 & 154.76 & 53.70 & 141.05 & 8.86 & 58.69 & 2.42 & 9.55 & 0.51 & 431.72 & 2.06 & 4.78 \\
\hline Prieta & 15 & 0.99 & 26.48 & 66.96 & 34.24 & 11.32 & 13.04 & 0.54 & 7.14 & 0.77 & 161.48 & 1.04 & 4.78 \\
\hline Casado & 16 & 1.49 & 39.42 & 275.98 & 61.30 & 0.00 & 32.68 & 1.89 & 12.06 & 0.66 & 425.48 & 2.08 & 6.98 \\
\hline Fuentes & 17 & 0.98 & 53.68 & 122.42 & 42.63 & 0.00 & 10.71 & 0.63 & 5.39 & 0.58 & 237.02 & 1.10 & 5.51 \\
\hline Obdulina & 18 & 0.99 & 47.41 & 203.65 & 56.65 & 0.00 & 37.89 & 2.05 & 10.58 & 0.7 & 360.00 & 1.75 & 2.57 \\
\hline Pardona & 19 & 1.24 & 22.27 & 63.13 & 24.66 & 26.23 & 9.29 & 0.49 & 5.28 & 0.3 & 152.98 & 1.18 & 6.49 \\
\hline No Prieta Antigua & 20 & 0.68 & 0.00 & 108.28 & 0.00 & 34.40 & 32.23 & 1.46 & 2.91 & 0.52 & 180.48 & 0.86 & 0.74 \\
\hline Arbeya & 21 & 0.70 & 73.62 & 163.64 & 75.03 & 9.02 & 32.75 & 1.76 & 8.07 & 0.69 & 365.28 & 1.58 & 4.17 \\
\hline Arbeya Montés & 22 & 0.76 & 102.71 & 167.93 & 75.82 & 10.31 & 33.69 & 1.77 & 7.04 & 0.68 & 400.71 & 1.52 & 5.15 \\
\hline Lin & 23 & 1.30 & 47.27 & 350.53 & 40.68 & 4.22 & 46.52 & 2.23 & 9.34 & 0.5 & 502.60 & 2.36 & 5.15 \\
\hline Blanquina & 24 & 0.98 & 9.32 & 193.24 & 23.11 & 0.00 & 10.44 & 0.00 & 13.85 & 0.52 & 251.46 & 1.00 & 3.80 \\
\hline Clara & 25 & 0.00 & 61.42 & 116.66 & 89.59 & 12.65 & 34.88 & 1.09 & 7.22 & 0.60 & 324.11 & 2.42 & 1.59 \\
\hline Coloradona & 26 & 1.39 & 47.95 & 63.83 & 59.95 & 31.89 & 14.75 & 0.80 & 7.31 & 0.4 & 228.34 & 1.70 & 1.35 \\
\hline Collaos & 27 & 1.11 & 6.93 & 93.26 & 9.57 & 6.70 & 40.70 & 2.50 & 6.69 & 0.54 & 168.00 & 1.14 & 4.04 \\
\hline Cristalina & 28 & 0.89 & 0.00 & 57.58 & 0.00 & 0.00 & 5.85 & 0.00 & 2.83 & 0.00 & 67.15 & 0.75 & 2.94 \\
\hline De La Riega & 29 & 1.13 & 8.68 & 195.56 & 22.50 & 6.44 & 3.66 & 0.00 & 3.65 & 0.36 & 241.98 & 1.23 & 4.29 \\
\hline Durón Encarnado & 30 & 0.89 & 19.12 & 115.00 & 26.72 & 5.10 & 11.64 & 0.63 & 5.80 & 0.66 & 185.56 & 1.07 & 5.27 \\
\hline Durona Tresali & 31 & 2.21 & 50.44 & 225.52 & 47.31 & 34.37 & 30.59 & 1.74 & 17.16 & 1.20 & 410.54 & 1.54 & 5.64 \\
\hline Fresnosa & 32 & 0.80 & 17.18 & 87.77 & 27.51 & 13.66 & 4.42 & 0.00 & 2.49 & 0.88 & 154.71 & 1.23 & 4.66 \\
\hline Limón Montés & 33 & 0.72 & 15.69 & 162.71 & 22.97 & 5.51 & 9.15 & 0.46 & 9.83 & 0.48 & 227.52 & 1.30 & 5.76 \\
\hline Mariñana & 34 & 0.82 & 21.96 & 21.24 & 31.63 & 0.00 & 12.77 & 0.65 & 6.58 & 0.62 & 96.27 & 0.96 & 3.31 \\
\hline Panquerina & 35 & 1.19 & 41.71 & 78.56 & 65.76 & 10.50 & 11.53 & 0.44 & 8.42 & 0.8 & 218.91 & 1.17 & 3.43 \\
\hline Paraquas & 36 & 0.49 & 0.00 & 126.17 & 6.98 & 4.90 & 8.05 & 0.37 & 4.70 & 0.5 & 152.21 & 1.10 & 2.21 \\
\hline Рepa & 37 & 0.48 & 0.00 & 136.57 & 6.79 & 0.00 & 8.74 & 0.00 & 3.26 & 0.57 & 156.41 & 1.27 & 1.72 \\
\hline Perezosa & 38 & 0.33 & 0.00 & 63.68 & 8.01 & 3.44 & 8.23 & 0.00 & 3.49 & 0.00 & 87.18 & 0.77 & 3.92 \\
\hline Perico & 39 & 1.18 & 24.38 & 143.42 & 20.27 & 8.27 & 38.48 & 1.87 & 8.04 & 0.5 & 246.43 & 1.22 & 3.68 \\
\hline Raxao & 40 & 1.00 & 20.48 & 84.58 & 18.14 & 5.10 & 36.25 & 1.81 & 6.32 & 0.52 & 174.43 & 0.87 & 4.78 \\
\hline Regona & 41 & 2.97 & 20.45 & 130.59 & 29.59 & 48.25 & 22.65 & 1.08 & 24.13 & 0.66 & 280.37 & 1.70 & 7.72 \\
\hline Repinaldo Gozón & 42 & 0.80 & 54.65 & 40.81 & 39.48 & 9.61 & 7.75 & 0.00 & 4.44 & 0.81 & 158.35 & 0.92 & 2.08 \\
\hline Solarina & 43 & 0.77 & 57.97 & 96.80 & 108.92 & 10.29 & 10.06 & 0.00 & 6.52 & 0.67 & 292.00 & 1.36 & 3.55 \\
\hline Teórica & 44 & 0.80 & 38.26 & 95.19 & 29.76 & 8.21 & 3.30 & 0.00 & 5.96 & 0.43 & 181.91 & 0.92 & 6.00 \\
\hline Verdialona & 45 & 0.00 & 15.47 & 74.87 & 25.86 & 9.3 & 7.38 & 0.39 & 3.51 & & 137.55 & 0.92 & 2.57 \\
\hline Xuanina & 46 & 0.00 & 24.14 & 144.92 & 41.06 & 0.00 & 36.88 & 2.11 & 6.46 & 0.69 & 256.26 & 1.08 & 4.78 \\
\hline mean & & 1.16 & 38.37 & 126.96 & 44.27 & 10.44 & 24.58 & 1.16 & 8.62 & 0.59 & & 1.36 & 4.11 \\
\hline & & 0.87 & 45.27 & 66.31 & 39.42 & 11.43 & 19.79 & 1.19 & 6.07 & & 121.78 & 0.45 & 1.46 \\
\hline maximum & & 4.47 & 246.92 & 350.53 & 206.54 & 48.25 & 107.18 & 6.52 & 32.39 & 1.20 & 688.56 & 2.42 & 7.72 \\
\hline minimum & & 0.00 & 0.00 & 21.24 & 0.00 & 0.00 & 3.30 & 0.00 & 2.49 & 0.00 & 67.15 & 0.75 & 0.74 \\
\hline
\end{tabular}

a Abbreviations: PHA1, phenolic acid derivative $(\lambda=316.7 \mathrm{~nm})$; CA, chlorogenic acid; $\mathrm{E},(-)$-epicatechin; PHA2, phenolic acid derivative $(\lambda=312 \mathrm{~nm})$; Ph XyG, phloretin xyloglucoside; Unk, unknown dihydrochalcone; Ph G, phloretin glucoside; PHA3, phenolic acid derivative $(\lambda=312 \mathrm{~nm}) ; \Sigma$, total polyphenols of low molecular mass; TP, total polyphenols (as grams of tannic acid per liter); TA, total acidity (as grams of sulfuric acid per liter); SD, standard deviation.

PCA. PCA was carried out to reduce the number of variables and to define the structure of the data. Three significant components, which accounted for $74.9 \%$ of the variance, were computed and validated by means of a single-cross full-validation procedure that uses the search for a local minimum prediction residual error square sum (PRESS) as criterion. Phloridzin, (-)epicatechin, and the unknown dihydrochalcone were removed from the original data matrix because they contributed to the same information as PHA1, procyanidin B2, and phloretin 2-xyloglucoside, respectively. Then, a new PCA was carried out by taking into account only the six relevant variables. The same explained variance was obtained using the first three significant factors. A bipl ot constructed from the first two principal components is displayed in Figure 3. As can be seen in this figure, we were able to establish two groups of variables: on the one hand, $\mathrm{PHA} 1, \mathrm{~B} 2$, and $\mathrm{PHA} 2$ were correlated to the first factor, and, on the other, chlorogenic acid and phl oretin 2-xyloglucosi de were correlated to the second factor. Likewise, a structure of data can be assessed from this plot. For instance, the Parda Blanquera (12) variety was placed in the upper righthand corner of the factorial plane, because this variety showed a high content of procyanidin $\mathrm{B} 2, \mathrm{PHA} 1$, and PHA2; however, its chlorogenic acid content was relatively low. In contrast, the Cristal ina (28) and Perezosa (38) varieties were placed in the upper left-hand corner of the factorial plane, which shows that these varieties have a low content of polyphenols of low molecular mass (Table 1). The Cristalina and Perezosa varieties, together with the Dolores and No Prieta Antigua varieties 
Table 2. Phenolic Compound Concentrations in Apple J uice Cultivars (1994 Harvest)a

\begin{tabular}{|c|c|c|c|c|c|c|c|c|c|c|c|c|c|}
\hline \multirow[b]{2}{*}{ variety } & \multicolumn{13}{|c|}{ polyphenols (mg/L) } \\
\hline & ref & PHA1 & B2 & CA & E & PHA2 & Ph XyG & Unk & Ph G & PHA3 & $\Sigma$ & $\mathrm{TP}$ & TA \\
\hline Calabaza & 1 & 1.71 & 31.09 & 196.67 & 49.16 & 18.98 & 30.75 & 1.30 & 9.54 & 0.85 & 340.04 & 1.29 & 5.51 \\
\hline Campillo & 2 & 4.03 & 35.14 & 84.29 & 39.78 & 0.00 & 73.92 & 3.19 & 11.76 & 0.44 & 252.55 & 1.00 & 3.92 \\
\hline Durón Arroes & 3 & 2.24 & 16.93 & 216.39 & 31.71 & 3.89 & 33.59 & 1.24 & 19.15 & 0.99 & 326.14 & & \\
\hline Dolores & 4 & 0.61 & 0.00 & 74.98 & 10.51 & 6.84 & 19.95 & 0.81 & 6.53 & 0.48 & 120.70 & 0.59 & 4.17 \\
\hline Lagar & 5 & 1.86 & 151.17 & 377.06 & 190.84 & 21.54 & 159.06 & 8.41 & 17.04 & 0.93 & 927.92 & 2.06 & 4.17 \\
\hline Miyares & 6 & 1.73 & 49.69 & 70.33 & 66.13 & 31.49 & 51.94 & 2.13 & 18.15 & 0.93 & 292.52 & 1.42 & 3.55 \\
\hline Reineta Encarnada & 7 & 0.89 & 28.78 & 119.17 & 49.73 & 3.81 & 11.63 & 0.52 & 6.60 & 0.81 & 221.94 & 1.04 & 4.90 \\
\hline Repinaldo Hueso & 8 & 1.02 & 27.92 & 177.14 & 36.83 & 0.00 & 7.66 & 0.24 & 4.17 & 0.37 & 255.36 & 1.25 & 5.02 \\
\hline Loroñesa & 9 & 1.93 & 18.73 & 339.11 & 29.59 & 19.02 & 36.23 & 1.29 & 13.95 & 0.63 & 460.47 & 1.56 & 4.29 \\
\hline Montoto & 10 & 2.84 & 55.66 & 155.23 & 86.00 & 0.00 & 37.88 & 1.93 & 9.70 & 0.59 & 349.84 & 1.46 & 4.41 \\
\hline Parda Carreño & 11 & 0.93 & 11.13 & 160.75 & 17.46 & 0.00 & 50.34 & 2.28 & 14.04 & 0.75 & 257.69 & 0.98 & 4.53 \\
\hline Parda Blanquera & 12 & 2.88 & 114.12 & 84.02 & 157.24 & 26.94 & 26.66 & 0.49 & 30.00 & 0.67 & 443.02 & 1.71 & 5.08 \\
\hline Loroñe & 13 & 3.23 & 153.37 & 82.61 & 190.76 & 25.24 & 27.29 & 0.53 & 28.80 & 0.68 & 512.52 & 1.88 & 5.00 \\
\hline Meana & 14 & 1.67 & 222.95 & 54.42 & 234.56 & 0.00 & 78.00 & 3.31 & 9.76 & 0.47 & 605.13 & 1.74 & 4.90 \\
\hline Prieta & 15 & 0.66 & 11.22 & 183.76 & 23.43 & 0.00 & 26.16 & 1.19 & 7.13 & 0.94 & 254.49 & 0.92 & 3.80 \\
\hline Casado & 16 & 1.93 & 66.06 & 309.44 & 106.41 & 0.00 & 44.27 & 2.36 & 13.86 & 0.76 & 545.08 & 1.70 & 7.35 \\
\hline Fuentes & 17 & 1.23 & 61.08 & 155.56 & 54.46 & 0.00 & 12.84 & 0.54 & 7.37 & 0.76 & 293.83 & & \\
\hline Obdulina & 18 & 0.79 & 56.24 & 190.68 & 77.23 & 0.00 & 39.31 & 1.87 & 10.63 & 0.85 & 377.60 & 1.34 & 2.82 \\
\hline Pardona & 19 & 1.58 & 49.44 & 109.03 & 54.20 & 39.06 & 8.57 & 0.64 & 7.11 & 0.54 & 270.16 & 1.15 & 7.23 \\
\hline Blanquina & 24 & 1.00 & 10.18 & 173.76 & 24.78 & 0.00 & 10.09 & 0.43 & 13.44 & 0.50 & 234.19 & 0.76 & 5.45 \\
\hline Clara & 25 & 0.00 & 62.51 & 100.97 & 126.16 & 8.97 & 43.17 & 1.55 & 13.75 & 0.71 & 357.80 & 1.43 & 1.47 \\
\hline Coloradona & 26 & 0.9 & 14.19 & 31.86 & 37.23 & 23.24 & 14.98 & 0.44 & 13.85 & 0.45 & 137.19 & 0.97 & 0.86 \\
\hline Collaos & 27 & 1.5 & 9.32 & 136.39 & 18.54 & 11.40 & 54.32 & 2.90 & 9.6 & 0.80 & 244.92 & 1.08 & 5.02 \\
\hline Cristalina & 28 & 1.27 & 0.00 & 63.16 & 5.01 & 0.00 & 8.93 & 0.33 & 5.37 & 0.43 & 84.50 & 0.57 & 3.80 \\
\hline De La Riega & 29 & 0.97 & 7.59 & 181.88 & 22.66 & 4.99 & 7.14 & 0.00 & 6.72 & 0.51 & 232.45 & 0.94 & 4.29 \\
\hline Durón Encarnado & 30 & 0.5 & 13.67 & 75.47 & 28.14 & 5.49 & 11.02 & 0.40 & 7.2 & 0.82 & 142.82 & 0.87 & 5.76 \\
\hline na Tresali & 31 & 1.5 & 44.15 & 174.08 & 52.11 & 36.62 & 29.77 & 1.29 & 17.42 & 1.0 & 358.08 & 1.24 & 5.64 \\
\hline Fresnosa & 32 & 1.94 & 29.90 & 116.32 & 50.53 & 17.43 & 6.32 & 0.22 & 3.89 & 1.28 & 227.84 & 1.06 & 5.20 \\
\hline Limón Montés & 33 & 0.81 & 18.87 & 199.09 & 31.79 & 4.39 & 9.85 & 0.25 & 8.98 & 0.62 & 274.65 & 1.05 & 6.13 \\
\hline Mariñana & 34 & 1.11 & 53.67 & 44.88 & 57.52 & 3.42 & 14.53 & 0.82 & 7.96 & 0.49 & 184.41 & 1.25 & 5.51 \\
\hline Panquerina & 35 & 1.65 & 42.76 & 89.50 & 60.03 & 10.86 & 9.79 & 0.38 & 6.39 & 0.59 & 221.95 & 1.24 & 4.66 \\
\hline Paraquas & 36 & 0.62 & 0.00 & 125.29 & 5.04 & 7.44 & 13.88 & 0.55 & 8.00 & 0.67 & 161.49 & 0.92 & 2.39 \\
\hline Pepa & 37 & 0.54 & 0.00 & 102.94 & 4.09 & 2.92 & 8.74 & 0.40 & 3.73 & 0.67 & 124.03 & 0.77 & 1.35 \\
\hline Perezosa & 38 & 0.58 & 9.58 & 107.06 & 21.40 & 5.16 & 16.35 & 0.67 & 5.59 & 0.00 & 166.39 & 0.74 & 4.17 \\
\hline Perico & 39 & 1.87 & 36.06 & 227.46 & 36.80 & 11.00 & 68.02 & 3.02 & 16.8 & 0.0 & 401.09 & 1.11 & 5.02 \\
\hline Raxao & 40 & 1.1 & 16.37 & 115.51 & 21.58 & 4.98 & 49.91 & 2.23 & 9.5 & 0.67 & 221.92 & 0.79 & 6.62 \\
\hline Regona & 41 & 4.06 & 21.71 & 130.13 & 53.99 & 68.34 & 27.84 & 1.04 & 36.61 & 0.93 & 344.65 & 1.20 & 7.96 \\
\hline Repinaldo Gozon & 42 & 0.78 & 43.06 & 25.07 & 42.49 & 4.36 & 6.84 & 0.32 & 4.31 & 0.66 & 127.89 & 0.71 & 2.70 \\
\hline Solarina & 43 & & 138.10 & 206.64 & 146.51 & 13.97 & 12.41 & 0.73 & 7.6 & & 527.93 & 1.85 & 4.53 \\
\hline Teórica & 44 & 0.9 & 23.21 & 112.87 & 25.41 & 6.67 & 4.03 & 0.00 & 7.4 & 0.54 & 181.11 & 0.74 & 5.76 \\
\hline Verdialona & 45 & 0.00 & 33.29 & 94.41 & 50.98 & 10.37 & 7.63 & 0.29 & 4.4 & 1.3 & 202.74 & 0.90 & 2.45 \\
\hline Xuanina & 46 & 0.99 & 12.08 & 161.48 & 25.27 & 0.00 & 35.59 & 1.80 & 7.02 & 0.76 & 244.98 & 0.91 & 6.25 \\
\hline mean & & 1.43 & 42.88 & ك.J.14 & 58.43 & & & 1.29 & 11.22 & 0.68 & & 1.16 & \\
\hline SD & & 0.92 & 47.66 & 76.92 & 54.09 & 13.97 & 28.39 & 1.45 & 7.18 & 0.27 & 159.01 & 0.37 & 1.58 \\
\hline maximum & & 4.06 & 222.95 & 377.06 & 234.56 & 68.34 & 159.06 & 8.41 & 36.61 & 1.36 & 927.92 & 20.6 & 7.96 \\
\hline minimum & & 0.00 & 0.00 & 25.07 & 4.09 & 0.00 & 4.03 & 0.00 & 3.73 & 0.00 & 84.50 & 0.57 & 0.86 \\
\hline
\end{tabular}

a Abbreviations: see Table 1.

(4 and 20), presented the lowest Folin index (Table 1); however, the latter ones had higher levels for phenols as determined by HPLC, mainly CA. It was also possible to visualize other groupings of samples: varieties with a high content of chlorogenic acid (5, 16, 18, 23, and 31) scored negatively with respect to the second principal component; other varieties, however, such as Loroñe, Meana, and Regona (13, 14, and 41), which showed a high content of PHAl and a relatively low chlorogenic acid content, were placed in the upper right-hand quadrant of the factorial plane.

At the same time, it was possible to draw a borderline in Figure 3 to differentiate the cider apple varieties with bitter and nonbitter properties. We categorized the samples from the structure visualized in the factorial plot as follows: the bitter class (B, 15 varieties), samples inside the borderline, and the nonbitter class $(\mathrm{N}, 31$ varieties), samples outside the border; $87 \%$ of samples belonging to the bitter category presented contents for total phenol $>1.5 \mathrm{~g} / \mathrm{L}$, and $90 \%$ of samples belonging to the nonbitter category presented total phenol contents $<1.5 \mathrm{~g} / \mathrm{L}$ (Tables 1 and 2 ).
LDA. The use of the LDA technique allowed us to correctly discriminate apple varieties belonging to the $\mathrm{B}$ and $\mathrm{N}$ categories (correct classifications $=100 \%$ ). The mathematical rule computed was validated using three groups for cancellation; the prediction matrix obtained is shown in Table 3. As can be seen, correct predictions were $91.3 \%$, which allows us to assert that this classification procedure is sufficiently robust. The most relevant variables for discriminating both categories were PHA1, chlorogenic acid, and phloretin 2-xyloglucoside. At the same time, the 42 cider apple varieties (harvested in 1994) included in the evaluation set (Table 2) were used in the external validation of the mathematical procedure computed. As can be seen in Table 4 , the predictive ability of the LDA method was adequate because $85.7 \%$ of the samples included in the evaluation set were correctly predicted. Samples incorrectly predicted were the Calabaza, Durón Arroes, Miyares, Collaos, Fresnosa, and Solarina varieties.

PLS Analysis. A PLS-1 analysis was performed using six polyphenols as predictor variables and the binary response as criterion variable. The variety 

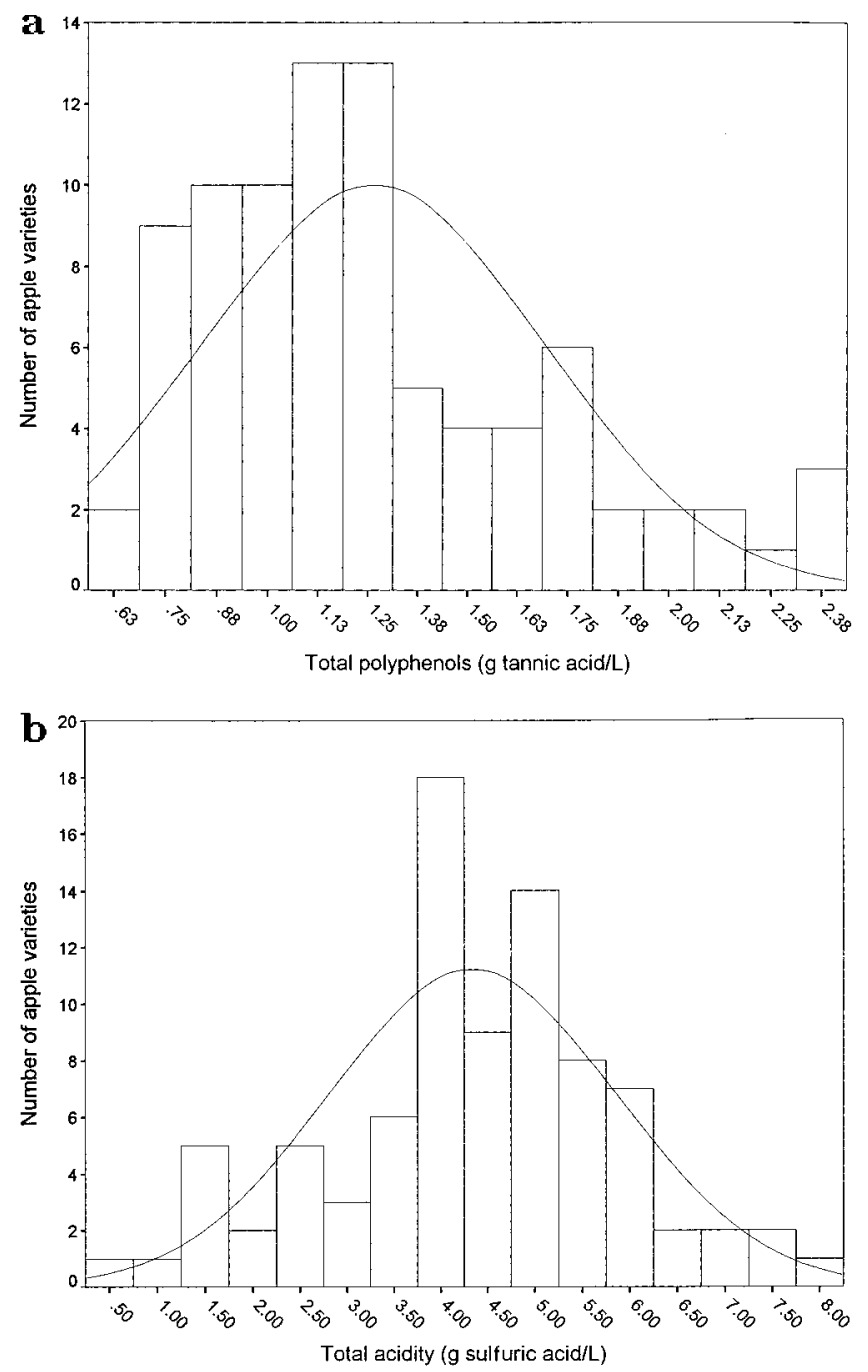

Figure 2. Global parameters in Spanish cider apple varieties: (a) total phenol contents (grams of tannic acid per liter); (b) total acidity (grams of sulfuric acid per liter).

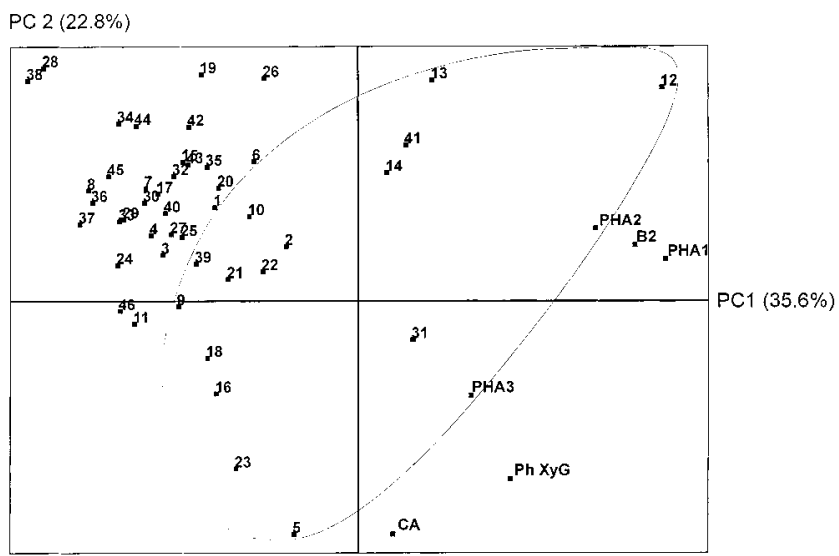

Figure 3. Projection of variables and samples on the factorial plane formed by the first two principal components. For abbreviations and reference numbers, see Table 1.

referred to as 12 was removed from the PLS-1 model because it was a leverage point. The PLS-1 model constructed consisted of one latent variable, the most relevant variables being, in order of importance, PHA1, phloretin 2-xyloglucoside, and chlorogenic acid, which is in accordance with the discriminant analysis. The model was validated by means of a cross-validation procedure, using three groups for cancellation, and

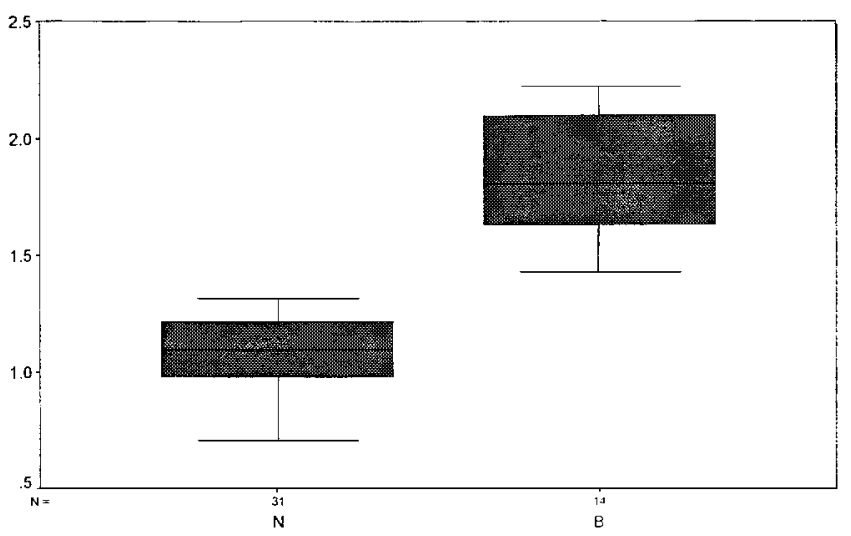

Figure 4. Multiple box and whisker plots for PLS computed values: $\mathrm{N}$, nonbitter; $\mathrm{B}$, bitter.

Table 3. Prediction Matrix (Three Cancellation Groups)

\begin{tabular}{cccc}
\hline & \multicolumn{3}{c}{ assigned category } \\
\cline { 2 - 4 } true category & $\mathrm{N}$ & $\mathrm{B}$ & hits(\%) \\
\hline N & 30 & 1 & 96.8 \\
B & 3 & 12 & 80.0 \\
overall & & & 91.3
\end{tabular}

Table 4. Prediction Matrix for the Evaluation Set

\begin{tabular}{crrr}
\hline & \multicolumn{3}{c}{ assigned category } \\
\cline { 2 - 4 } true category & N & B & hits(\%) \\
\hline N & 24 & 6 & 80.0 \\
B & 0 & 12 & 100.0 \\
overall & & & 85.7
\end{tabular}

exhibited a maximum cross-validated explained variance of $71.8 \%$ and a multiple linear correlation coefficient of $75.0 \%$ with one latent variable. Multiple box and whisker plots for PLS computed values are represented in Figure 4, showing a satisfactory differentiation of the two categories (bitter and nonbitter).

\section{DISCUSSION}

The contents of CA in our samples were higher than those reported by Delage et al. (1991) for some French cider varieties, even for the bitter ones, such as the cultivar Kermerrien, which should be related to the sample preparation procedure, consisting of extraction of polyphenols with ethyl acetate. Contents for flavanols such as (-)-epicatechin and procyanidin B2 were lower than those reported by Lea (1990) for English varieties but higher than those by Delage et al. (1991).

As said, total phenols and total acidity are used for classification of apple varieties into technological groups; however, important differences for phenolic profiles can be found. For example, the varieties named as bitter presented differences that are important to the technological point of view. As said, the most discriminant variables were PHA1, chlorogenic acid, and phloretin 2-xyloglucoside. Samples incorrectly assigned as bitter in the LDA model presented in the evaluation set higher contents for PHA1, CA, and phloretin 2-xyloglucoside; thus, they were included in the bitter category, although their total phenol levels were lower in the 1994 harvest than in the 1995 harvest (except for the Solarina variety). Among these phenolics, chlorogenic acid is one of the most important substrates for polyphenol oxidase (PPO); its oxidation gives rise to pigments that can cooxidize other substances (Ami ot et al., 1992). Therefore, cider apple varieties with a low concentration of chlo- 
rogenic acid would be more appropriate for apple juice making, to minimize enzymatic browning, and to control the stability of the final product. For this reason, we could say that varieties referred to as $5,9,16,18,23$ and 31 (Figure 3 ) are not suitable for apple juice making.

Phenolic acids also contribute to cider flavor; on the one hand, they can act as precursors for volatile phenols, due to the metabolism of bacteria of the genus Lactobacillus and yeasts of the genera Saccharomyces and Brettanomyces (Beech and Carr, 1977; Chatonnet et al., 1992, 1993), which can produce undesirable off-flavors if they surpass the acceptability threshold. On the other hand, phenolic acids such as chlorogenic acid can have a subtle contribution to the astringency of beverages (Naish et al., 1993).

Flavan-3-ols are also substrates for PPO, although less so than chlorogenic acid, and can also be oxidized by the o-quinone of chlorogenic acid by a coupled mechanism, giving rise to highly colored pigments. In fact, the degree of browning of apples was found to be dependent on the relationship hydroxycinnamic derivatives/flavan-3-ols (Amiot et al., 1992). These authors suggested that both the chlorogenic acid and the relative balance of hydroxycinnamics to flavanols should be considered in the susceptibility to browning. All of the varieties analyzed presented lower (-)-epicatechin and procyanidin B2 levels than the English ones used for cider-making (Lea, 1990). Although lower contents in flavan-3-ols should be considered an advantage in terms of the stability of cider with respect to haze, we also have to keep in mind both their positive contribution to the taste of cider and the ability of these polyphenols to control microbiological spoilage. In this sense, it should be pointed out that the use of cider apple varieties with very low contents of polyphenols (e.g., the Cristalina and Perezosa varieties) could promote several faults caused by lactic acid bacteria such as acidification, mannitol taint, and ropiness.

\section{CONCLUSIONS}

The analysis of polyphenols of low molecular mass in Spanish cider apple varieties has been successfully accomplished by HPLC with direct injection. I n general terms, the content of flavanols was lower than that reported for English cider apple varieties but higher than that described in some French cider apples. The use of PCA allowed us to visualize technol ogical groups of the varieties based on their phenolic profiles and to identify their potential use for manufacturing processed apple products. Finally, the mathematical decision rule computed by LDA and the PLS-1 model constructed allowed us to carry out a suitable prediction of the category to which the cider apple varieties belong. Chlorogenic acid, phloretin 2-xyloglucoside, and the compound referred to as PHA-1 were the most relevant variables for discriminating apple varieties into bitter and nonbitter categories.

\section{LITERATURE CITED}

Amiot, M. J .; Tacchini, M.; Aubert, S.; Nicolas, J. Phenolic composition and browning susceptibility of various apple cultivars at maturity. J . Food Sci. 1992, 57, 958-962.

AOAC. Official Methods of Analysis; Williams, S., Ed.; Association of Official Analytical Chemists: Arlington, VA, 1984.
Beech, F. W.; Carr, J. G. Cider and perry. In Alcoholic Beverages; Rose, A. H., Ed.; Academic Press: London, U.K., 1977; Chapter 3, pp 139-313.

Betés-Saura, C.; Andrés-Lacueva, C.; Lamuela-Raventós, R. $M$. Phenolics in white free run juices and wines from Penedés by high performance liquid chromatography: changes during vinification. J. Agric. Food Chem. 1996, 44, 3040-3046.

Chatonnet, P.; Dubourdieu, D.; Boidron, J .-N.; Pons, M. The origin of ethylphenols in wines. J . Sci. Food Agric. 1992, 60, 165-178.

Chatonnet, P.; Dubourdieu, D.; Boidron, J .-N.; Lavigne, V. Synthesis of volatile phenols by Saccharomyces cerevisiae in wines. J. Sci. Food Agric. 1993, 62, 191-202.

Chen, J . H.; Ho, C.-T. Antioxidant activities of caffeic acid and its related hydroxycinnamic acid compounds. J . Agric. Food Chem. 1997, 45, 2374-2378.

Delage, E.; Bohuon, G.; Baron, A.; Drilleau, J. F. Highperformance liquid chromatography of the phenolic compounds in the juice of some F rench cider apple varieties. J . Chromatogr. 1991, 555, 125-136.

Donovan, J. L.; Meyer, A. S.; Waterhouse, A. L. Phenolic composition and antioxidant activity of prunes and prune juice (Prunus domestica). J . Agric. Food Chem. 1998, 46, 1247-1252.

Escarpa, A.; González, M. C. High-performance liquid chromatography with diode-array detection for the determination of phenolic compounds in peel and pulp from different apple varieties. J . Chromatogr. A 1998, 823, 331-337.

Forina, M.; Leardi, R.; Armanino, C.; Lanteri, S. In PARVUS. An Extendable Package of Programs for Data Exploration, Classification and Correlation; Elsevier: Amsterdam, The Netherlands, 1988.

Guyot, S.; Marnet, N.; Djamel, L.; Sanoner, P.; Drilleau, J .-F . Reversed-phase HPLC following thiolysis for quantitative estimation and characterization of the four main classes of phenolic compounds in different tissue zones of a French cider apple variety (Malus domestica Var. Kermerrien). J . Agric. Food Chem. 1998, 46, 1698-1705.

Lea, A. G. H. Bitterness and astringency: the procyanidins of fermented apple ciders. In Bitterness in Food and Beverages; Rouseff, R. L., Ed.; Elsevier: Amsterdam, The Netherlands, 1990; pp 123-143.

Lee, C. Y.; J aworski, A. Phenolic compounds in white grapes grown in New York. Am. J. Enol. Vitic. 1987, 38, 277-281.

Macheix, J . J .; Fleuriet, A.; Billot, J . Phenolic compounds in fruit processing. In Fruit Phenolics; CRC Press: Boca Raton, FL, 1990a; pp 328-329.

Macheix, J . J .; Fleuriet, A.; Billot, J . Importance and roles of phenolic compounds in fruits. In Fruit Phenolics; CRC Press: Boca Raton, FL, 1990b; pp 265-271.

Martens, H.; Naes, T. Methods for calibration. Partial leastsquares regression (PLSR). In Multivariate Calibration; Wiley: Chichester, U.K., 1989; pp 116-119.

Massart, D. L.; Vandeginste, B. G. M.; Deming, S. N.; Michotte, Y.; Kaufman, L. Supervised pattern recognition. In Chemometrics: A Textbook; Vandeginste, B. G. M., Kaufman, L., Eds.; Elsevier: Amsterdam, The Netherlands, 1988; pp 385-387.

Meloun M.; Militký, J .; Forina, M. Exploratory and factor analysis of multivariate data. In Chemometrics for Analytical Chemistry; Masson, M. Ed.; Ellis Horwood: New York, 1992; pp 212-300.

Montreau, F. Total phenol analysis in wines by the FolinCiocalteu method. Connais. Vigne Vin 1972, 6, 397-404.

Naish, M.; Clifford, M. N.; Birch, G. G. Sensory astringency of 5-O-caffeoylquinic acid, tannic acid and grape-seed tannin by a time-intensity procedure. J . Sci. Food Agric. 1993, 61, 57-64.

Nicolas, J . J .; Richard-F orget, F. C.; Goupy, P. M.; Ami ot, M. J .; Aubert, S. Y. Enzymatic browning reactions in apple and apple products. Crit. Rev. Food Sci. Nutr. 1994, 34, 109157. 
Okuda, T. Natural polyphenols as antioxidants and their potential use in cancer prevention. In Polyphenolic Phe nomena; Scal bert, A., Ed.; INRA Editions: Paris, France, 1993; pp 221-235.

Picinelli, A.; Suárez, B.; Mangas, J . J . Analysis of polyphenols in apple products. Z. Lebensm. Unters. F orsch. A 1997, 204, 48-51.

Robichaud, J . L.; Noble, A. C. Astringency and bitterness of selected phenolics in wine. J . Sci. Food Agric. 1990, 53, 343353.

Salagoity-Auguste, M. H.; Bertrand, A. Wine phenolic analysis of low molecular weight components by HPLC. J . Sci. Food Agric. 1984, 35, 1241-1247.

Siebert, K. J .; Troukhanova, N. V.; Lynn, P. Y. Nature of polyphenol-protein interaction. J . Agric. F ood Chem. 1996a, 44, 80-85.

Siebert, K. J .; Carrasco, A.; Lynn, P. Y. Formation of proteinpolyphenol haze in beverages. J . Agric. Food Chem. 1996b, 44, 1997-2005.
Suárez, B.; Santamaría, J .; Mangas, J . J .; Blanco, D. Highperformance liquid chromatography of the neutral phenolic compounds of low molecular weight in apple juice. J . Agric. Food Chem. 1994, 42, 2732-2736.

Suárez, B.; Picinelli, A.; Mangas, J . J . Solid-phase extraction and high-performance liquid chromatographic determination of polyphenols in apple musts and ciders. J . Chromatogr. 1996, 727, 203-209.

Suárez, B.; Picinelli, A.; Moreno, J .; Mangas, J .J . Changes in phenolic composition of apple juices by HPLC with direct injection. J . Sci. Food Agric. 1998, 78, 461-465.

Received for review April 5, 1999. Revised manuscript received J uly 19, 1999. Accepted J uly 26, 1999. We are indebted to the Instituto Nacional de Investigación Agraria (INIA, Project SC93/089) and the Principado de Asturias for financial support.

J F 9903197 